\title{
Using ichthyotoxic plants as bioinsecticide: A literature review
}

\author{
ANDRADE, J.N. ${ }^{1}$; COSTA NETO, E.M. ${ }^{* ;}$; BRANDÃO, H.2 \\ ${ }^{1}$ Feira de Santana State University (UEFS); Department of Biology. Av. Transnordestina, s/n, bairro Novo \\ Horizonte, Feira de Santana - BA, CEP 44036-900. ' Feira de Santana State University (UEFS); Department of \\ Health. Av. Transnordestina, s/n, bairro Novo Horizonte, Feira de Santana - BA, CEP 44036-900. *Author for \\ correspondence: eraldont@hotmail.com
}

\begin{abstract}
Some ichthyotoxic plants are study object aiming to discover promising substances in the field of Biotechnology, in search of plant extracts which can be used or even transformed into natural insecticides. This paper presents a bibliographical survey in order to check the traditional use of ichthyotoxic plants as bioinsecticide. Among the plants identified as ichthyotoxic, the most cited in traditional use are those from the genera Derris, Serjania, Lonchocarpus, Magonia, and Tephrosia. The survey suggests that ichthyotoxic plant extracts can contain classes of chemical compounds such as isoflavonoids and tannins with a bioinsecticidal effect and, thus, they can be used in Biotechnology, contributing to reduce the use of synthetic insecticides that present a high toxicity level.
\end{abstract}

Keywords: ichthyotoxic plants, bioinsecticide, plant extracts, biotechnology.

RESUMO: Uso de plantas ictiotóxicas como bioinseticida: revisão de literatura. Algumas plantas ictiotóxicas são objeto de estudos com a finalidade de descobrir substâncias promissoras no campo da Biotecnologia, na busca de extratos vegetais que possam ser usados ou mesmo transformados em inseticidas naturais. Esse artigo apresenta uma pesquisa bibliográfica sobre o uso tradicional de plantas ictiotóxicas como bioinseticida. Entre as plantas identificadas como ictiotóxicas, as mais citadas no uso tradicional são as dos gêneros Derris, Serjania, Lonchocarpus, Magonia e Tephrosia. A pesquisa sugere que extratos de plantas ictiotóxicas podem conter classes de compostos químicos, como isoflavonoides e taninos, com efeito bioinseticida e, assim, podem ser usados na Biotecnologia, contribuindo na redução do uso de inseticidas sintéticos que possuem alto nível de toxicidade.

Palavras-chave: Plantas ictiotóxicas, bioinseticida, extrato vegetal, biotecnologia.

\section{INTRODUCTION}

Insects represent the most abundant animal group on Earth, since more than 750,000 living species of insects have already been described by science, although estimates indicate a number of 30 million species (Erwin, 1997). Insects perform essential services for the maintenance of most ecosystems (Vane-Wright \& Waage, 1991; Fisher, 1998), playing important ecological roles, such as nutrient cycling, pollination of flowering plants, seed dispersion, maintenance of soil structure and fertility, waste treatment, control of organism populations, direct food source for numerous animal species, genetic resources etc. Whereas many insects are harmless to human beings and help in pollination of plants, there are those which are regarded as pests, affecting the country's agriculture and economy, as other ones are vectors of organisms which can cause major epidemics, reaching the level of a public health problem (López-Antuñano, 1992).

Some endemic diseases in Brazil, such as dengue fever, malaria, arboviral diseases, and yellow fever, have mosquito species as vectors which are currently resistant to various classes of chemical insecticides (Teixeira, 2003). According to Oliveira Filho (2002), the species Culex quinquefasciatus Say, 1823 and Aedes aegypti Linnaeus, 1762 have developed resistance to many insecticides commonly used in urban areas by the vector control programs. Populations of $A$. aegypti in 20 municipalities of various Brazilian states have showed resistance, especially to temephos (Donalísio \& Glasser, 2002). This situation encourages the research of natural 
products, and some studies indicate compounds of botanical origin with larvicidal activity and potential for use in vector control.

In order to keep under control the population of these animals which cause some kind of harm to human health, significant sums are annually aimed at programs against these vectors. The use of synthetic insecticides in public health programs for the control of some insect species by eliminating their larval or winged forms has been the most applied strategy in Brazil (Oliveira Filho, 2002). However, excessive fight against the vector with synthetic insecticides is a serious threat to the environment and it poses a serious risk to the population health, especially for those who directly manipulate these products. These products have some toxicity level, and they can also contribute to insects' resistance. Pizarro et al. (1999) have already indicated difficulties for controlling insects, such as $A$. aegypti and C. quinquefasciatus, due to the emergence of resistance to various insecticide groups still used nowadays, such as organochlorines, organophosphates, carbamates, and pyrethroids. Thus, there are several factors encouraging the development of practices for using natural insecticides, especially the economic and environmental ones.

Since ancient times, man uses crude plant extracts for insecticide purposes, a practice which still persists today, contributing to form a body of knowledge on nearly 200 species with such an activity (Corrêa, 2006). This way, alternative measures have been tested with regard to the use of plants (Penteado, 2000) potentially lethal to insects (Pizarro et al., 1999). Some plant metabolites with insecticidal activities, such as alkaloids, rotenoids and polyphenols, are regarded as ideal to be used in integrated pest management, because one thinks they are less harmful to the environment (Castiglioni \& Vendramim, 2003).

The first insecticides derived from plant extracts were nicotine, rotenone, and pyrethrin, which were replaced after the emergence of organochlorine insecticides, which showed to be more efficient and cheaper (Corrêa, 2006). Although pyrethroids present various toxicity levels, it has been shown that exposure of mammals to these insecticides, in an acute or subchronic way, induced several signs of neurotoxicity, such as shivers and convulsions (Kolaczinski \& Curtis, 2004; Shafer et al., 2005). Along with the health risk, these compounds found in synthetic insecticides have caused environmental impact, since they contribute to soil, water, and living beings contamination (Raizada et al., 2001; Abdollahi et al., 2004; Nakata et al., 2005).

The compounds found in some plant extracts have effects on insects ranging from repellency to death in different stages, by inhibiting feeding, alterations in the hormonal system, or blocking cell respiration (Pizarro et al., 1999). Ethnobotanical studies based on the use of traditional knowledge information help unraveling these plant resources of economic importance. Traditional knowledge consists of information or individual or collective practice from an indigenous or local community, with actual or potential value associated to genetic heritage (Brasil, 2012). Thus, the discovery of natural extracts through this knowledge can be an ally for maintaining environmental balance and control of some vectors.

Some studies reported the use of plants based on popular knowledge as an alternative to control pests and disease vectors, such as, for instance, Derris amazonica Killip, used by traditional peoples due to its toxic action level (Pizarro et al., 1999; Alécio et al., 2010). In Malaysia, the cultivation of this genus was done along with the pepper to combat insect pests that attacked the latter. The modern use of rotenone, trade name of the insecticide, has expanded in the cultivation of vegetables, tobacco, etc., since it shows toxic to insects but not to humans (León, 1968).

Among the vegetables with high toxic action, one highlights the plants known as ichthyotoxic, which have substances with biotechnological potential commonly used in fishing activity and which can present insecticidal activity, depending on their toxicity, according to the presence of secondary metabolites, such as polyphenols, over the different life stages of some insects. Currently, researches have been carried out with the aim of knowing the metabolites found in these plants and responsible for the toxic action (Pizarro et al., 1999; Homma, 2004).

This study aimed to compare and report the various traditional uses of ichthyotoxic plants as bioinsecticide to control insects which are pest and disease vectors.

\section{Ichthyotoxic plants}

Indigenous peoples are responsible for transmitting valuable information in the field of Biology, for instance, information on the use of plant poisons in fishing. Indians in the Amazon region have the habit of using plant parts, like roots, stems, and leaves, to help catching fish, as well as controlling pests (Rizzini \& Mors, 1976; Costa et al., 1997; Kotze et al., 2006). Under the effect of these toxic substances, fishes usually tend to become stunned at the river water surface, facilitating their capture during fishing.

The ichthyotoxic plants are commonly known as timbó, but they have other popular designations, which range according to the site where they are found out, such as timbó-grande, timbó-legitimo, timbó-macaquinho, timbó-urubu, 
timbó-verdadeiro, timbó-jacaré, cipó-cururu, cipógrande, lombrigueira, timbó-açu, timbó-da-mata, timborana, timbó-cipó (in Brazil); barbasco (in Peru and Colombia) (Tozzi, 1998), or also timu (for Indians in Peru) (Krukoff \& Smith, 1937).

Species of the genera Lonchocarpus and Derris are usually reported in the literature, mainly because they have insecticidal action (Saito \& Luchini, 1998; Alécio et al., 2010) over various types of insects, due to the presence of toxins in some plant parts. Other genera were also reported in papers as potentially insecticide timbó species: Ateleia, Magonia, Serjania, Thinouia, and Tephrosia (Ortega \& Schenkel, 1987; Were et al., 1990; Silva et al., 2004; Souza \& Felfili, 2006; Rodrigues et al., 2006).

\section{plants \\ Bioinsecticide potential of ichthyotoxic}

In Brazil, there are references on the use of ichthyotoxic and insecticidal plants since the days of Piso, Castelnau, Wallace, and Anchieta, who referred to timbó species used in fishing by the Amerindians (Pires, 1978). Some authors stand out due to studies on plants regarded as ichthyotoxic and having insecticidal properties, such as Costa et al. (1999) and Saito \& Lucchini (1998).

In Spain, the first reference to the utilization of ichthyotoxic plants appears in a law which was promulgated in 1255 by King Alfonso X el Sabio and forbade their use (Álvarez Arias, 2000). This author has recorded at least 32 species (from 21 genera and 15 families) that have been used traditionally as ichthyotoxics, although this practice is disappearing today because only the most traditional people remember the secrets for their use.

Pharmacology is an important tool to help discovering plant extracts which can be used as natural insecticides. Plant secondary metabolites have a strong potential for eliminating pests and disease vectors with the production of new insecticides (Villalobos, 1996). According to Isman (2006), these products may also be in compliance with selectivity and efficacy requirements, besides being biodegradable, something which is expected in contrast to chemical insecticides, eliminating the risk to human health and damage to the environment.

Tests with extracts of timbó plants recognized the insecticidal potential over some insect species larvae. Extracts of Casearia sylvestris var. lingua (Cambess.) Eichler (hexane stem bark extract), Duguetia furfuracea (A.St.-Hil.) Benth. \& Hook, and Piptocarpha rotundifolia (Less.) Baker (hexane root extract), Serjania lethalis A.St.-Hil., and Annona crassiflora Mart. (ethanol root bark extract), Xylopia aromatica (Lam.) Mart. (ethanol leaf extract), and Magonia pubescens A. St.-Hil. (ethanol stem bark extract) showed a significant insecticidal activity over $A$. aegypti larvae (Arruda et al., 2003), and the compound was absorbed via ingestion (Coelho et al., 2009).

There are also positive results with regard to the toxicity of Derris amazonica for Cerotoma arcuatus Olivier, 1791, adult individuals, and the ingestion of contaminated leaves is the most effective one, followed by contact to contaminated surface and topical application (Alécio et al., 2010). Preliminary assays indicate that Antonia ovata Pohl (Loganiaceae) and D. amazonica have an insecticide effect on Lutzomyia longipalpis (Lutz \& Neiva, 1912), the main visceral leishmaniasis vector in Brazil (Luitgards-Moura et al., 2002).

The crude extract of the leaves and stem of Phyllanthus acuminatus Vahl (Phyllantaceae), as well as their different concentrations, were tested in larvae of $A$. aegypti checking the mortality rate at 24 and 48 hours at laboratory conditions to $25^{\circ} \mathrm{C}$ in a growth chamber to assess its action as biopesticide agent. Although not standardized a suitable dosage of a larvicide from natural plant extracts tested, it was found that in higher concentrations it is possible to achieve the desired effect contributing to breaking the cycle of development of dengue vector and contributing to the reduction the indiscriminate use of synthetic larvicides that have high power toxicity (Andrade, 2013).

\section{Major chemical classes of timbó species with bioinsecticide potential}

The ichthyotoxic plants usually have as secondary metabolites classes of compounds with lethal activities over some insects. A class which presents toxic activity over insects is that of isoflavonoids and rotenone (Figure 1) stands out among them, under the molecular formula $\mathrm{C}_{23} \mathrm{H}_{22} \mathrm{O}_{6}$. Some Leguminosae species are known to have roots rich in toxic substances, such as those named as timbó, regarded as ichthyotoxic mainly due to the presence of rotenoids (Tozzi, 1998). In the timbó plants extract, rotenoid and flavonoid compounds are represented by rotenone, tocopherol, degueline, tephrosine, and alpha-amisyn (Pizarro et al., 1999). According to Teixeira \& Rocha (2009), species belonging to timbó complexes usually have rotenone in their roots, a substance responsible for a strong and unpleasant odor and presenting toxicity over fishes.

Rotenone, which presents a molecular weight of 394.42 , is very soluble in many organic solvents, for example alcohol and acetone, but is almost completely insoluble in water (Hien et al., 2003). It is the most studied among the isoflavonoids and the most powerful of them, killing animals primarily by inhibiting the mitochondrial respiratory chain, and fishes show to be highly susceptible

Rev. Bras. PI. Med., Campinas, v.17, n.4, p.649-656, 2015. 


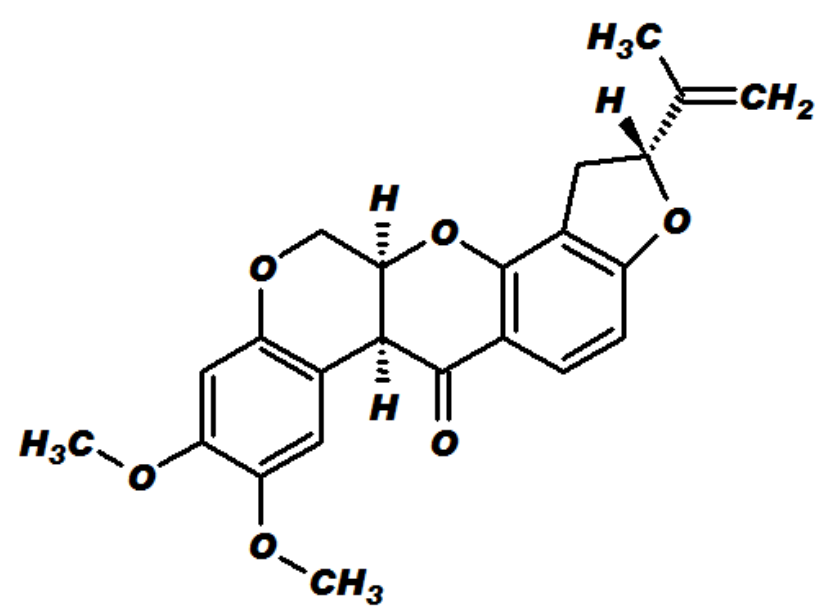

FIGURE 1. Structural formula of rotenone.

(Mascaro et al., 1998). According to Corrêa (2006), the roots of this plant, when crushed and stirred in water produce a milky juice with a very strong and peculiar smell, and, under the action of this juice, even very dilute, fishes lose their balance, emerge stunned to the surface, and, thus, they are easily caught.

Another class with potential action over insects is that of tannins (Figure 2), a phenolic substance, soluble in water, with molecular weight between 500 and $3.000 \mathrm{Da}$, which presents biological importance because it has strong interactions with metal ions and macromolecules, in addition to the ability to form soluble complexes with alkaloids

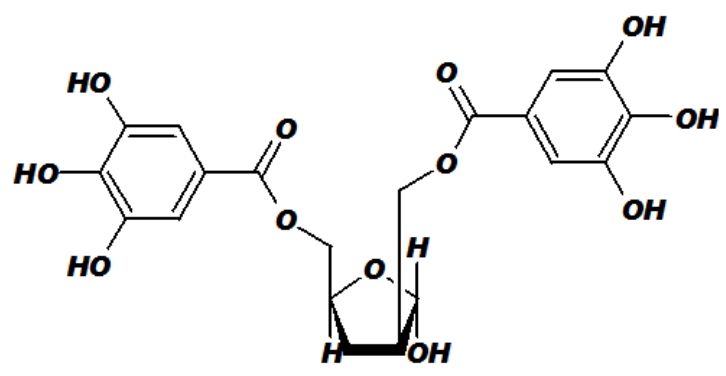

a) Hydrolyzable tannin and several proteins (Monteiro et al., 2005), since biological systems need these ions as enzymatic cofactors, something which makes this class toxic to insects and microorganisms, such as bacteria and fungi (Simões et al., 2004). An example of species with ichthyotoxic and insecticidal action attributed to tannins is Magonia pubescens A.St.-Hil., which has a lethal effect over $3^{\text {rd }}$ stage $A$. aegypti larvae (Silva et al., 2004).

Teixeira et al. (1984) reported that Serjania lethalis (Sapindaceae), a plant popularly used as ichthyotoxic, showed insecticidal activity. Besides having ichthyotoxic action (Mesquita et al., 2005), it also has an analgesic effect. Rodrigues et al. (2006) reported that ethanol extracts of its wood have a toxic effect over $A$. aegypti larvae. According to Coelho et al. (2009), serjanosids isolated from $S$. lethalis were 10 to 50 times more toxic than certain saponins, but 10 times less toxic than rotenone. Pizarro et al. (1999) report on the hemolytic and toxic activity which saponins have over fishes, besides the known biological and pharmacological activities, such as the anti-inflammatory, anti-allergenic, and immunomodulatory ones with regard to human beings.

The genus Derris (Fabaceae) is found in the literature as a reference of ichthyotoxic plant with action over mosquitoes, and this fact is due to the presence of flavonoid and rotenoid compounds, mainly rotenone and degueline, present in the root (Lima, 1987; Mascaro et al., 1998). This genus is often found out in the Amazon region and it has<smiles>Oc1cc(O)c2c(c1)OC(c1ccc(O)c(O)c1)C(O)C2c1c(O)cc(O)c2c1OC(c1ccc(O)c(O)c1)C(O)C2c1c(O)cc(O)c2c1OC(c1ccc(O)c(O)c1)C(O)C2</smiles>

b) Condensed tannin

FIGURE 2. Examples of (a) hydrolyzable tannin and (b) condensed tannin chemical structures. 
TABLE 1. Ethnobotanical information on timbó species with insecticidal action.

\begin{tabular}{|c|c|c|c|c|c|c|}
\hline Family & Genus & Species & Popular name & Phytocompound & Use & Author \\
\hline \multirow[t]{3}{*}{ Fabaceae } & Derris & $\begin{array}{l}\text { D. urucu } \\
\text { D. elliptica } \\
\text { D. nicou } \\
\text { D. negreensis } \\
\text { D. guianensis } \\
\text { D. malaccensis } \\
\text { D. uliginosa } \\
\text { D. amazonica }\end{array}$ & Timbó & $\begin{array}{l}\text { Rotenone, tocopherol, } \\
\text { degueline, tephrosine }\end{array}$ & $\begin{array}{l}\text { Indigenous people } \\
\text { employed it to poison } \\
\text { fishes. Chinese } \\
\text { horticulturists used } \\
\text { the roots since } \\
\text { ancient times as a } \\
\text { powerful insecticide. }\end{array}$ & $\begin{array}{c}\text { Decker } \\
(1942) \\
\text { Mors et al. } \\
(1973) \\
\text { Costa et al. } \\
(1997)\end{array}$ \\
\hline & Tephrosia & $\begin{array}{l}\text { T. toxicaria } \\
\text { T. virginiana } \\
\text { T. nitens }\end{array}$ & $\begin{array}{c}\text { Timbó-de-caiena } \\
\text { Timbó-caa }\end{array}$ & $\begin{array}{l}\text { Rotenone, tocopherol, } \\
\text { degueline, tephrosine }\end{array}$ & $\begin{array}{l}\text { Insecticidal and } \\
\text { ichthyotoxic activity. } \\
\text { Compounds generally } \\
\text { extracted from the } \\
\text { root. }\end{array}$ & $\begin{array}{l}\text { Were et al. } \\
\text { (1990), Tyler } \\
\text { et al. (1979) }\end{array}$ \\
\hline & Lonchocarpus & $\begin{array}{l}\text { L. utilis } \\
\text { L. urucu } \\
\text { L. floribundus }\end{array}$ & $\begin{array}{l}\text { Timbó-venenoso } \\
\text { Timbó-urucu } \\
\text { Cube }\end{array}$ & $\begin{array}{l}\text { Rotenone and } \\
\text { Flavonoids }\end{array}$ & $\begin{array}{l}\text { It has insecticidal and } \\
\text { ichthyotoxic action. } \\
\text { One often uses the } \\
\text { root to extract the } \\
\text { compounds. The } \\
\text { commercial source is } \\
\text { known as "cube" root } \\
\text { or timbó root. }\end{array}$ & $\begin{array}{l}\text { Saito \& } \\
\text { Luchini } \\
(1998)\end{array}$ \\
\hline Phyllanthaceae & Phyllanthus & acuminatus & - & $\begin{array}{l}\text { Flavonoids, tannins, } \\
\text { saponins, steroids, } \\
\text { triterpenoid, coumarins } \\
\text { and other terpenoids }\end{array}$ & $\begin{array}{c}\text { Piscicidal use among } \\
\text { artisanal fishermen } \\
\text { from Bahia State, } \\
\text { Brazil }\end{array}$ & $\begin{array}{l}\text { Andrade } \\
(2013)\end{array}$ \\
\hline \multirow[t]{2}{*}{ Sapindaceae } & Magonia & M. pubescens & $\begin{array}{c}\text { Tingui } \\
\text { Timbó-do-cerrado }\end{array}$ & $\begin{array}{l}\text { Tannins isolated from } \\
\text { the ethanol extract of } \\
\text { stems bark and trunks }\end{array}$ & $\begin{array}{c}\text { Piscicidal and } \\
\text { ichthyotoxic action. } \\
\text { Larvicidal activity over } \\
\text { Aedes aegypti and } \\
\text { A. albopictus. Used } \\
\text { for the preparation of } \\
\text { soaps for dermatitis, } \\
\text { seborrhea, to kill lice, } \\
\text { and as an insecticide. }\end{array}$ & $\begin{array}{c}\text { Souza \& } \\
\text { Felfili (2006), } \\
\text { Silva et al. } \\
\text { (2004) }\end{array}$ \\
\hline & Serjania & $\begin{array}{l}\text { S. fuscifolia } \\
\text { S. lethalis }\end{array}$ & Cipó-timbó & Timboina & $\begin{array}{c}\text { It has piscicidal and } \\
\text { insecticidal action. } \\
\text { Traditional medicine: } \\
\text { used as anesthetic } \\
\text { and anti-inflammatory } \\
\text { agent. Potential action } \\
\text { over Aedes aegypti } \\
\text { larvae. }\end{array}$ & $\begin{array}{l}\text { Arruda et al. } \\
\qquad(2003) \\
\text { Rodrigues et } \\
\text { al. (2006) }\end{array}$ \\
\hline Loganiaceae & Antonia & A. ovata & Timbó & & $\begin{array}{l}\text { Ichthyotoxic used for } \\
\text { fishing in Roraima }\end{array}$ & $\begin{array}{l}\text { Luitgards- } \\
\text { Moura et al. } \\
\text { (2002) }\end{array}$ \\
\hline
\end{tabular}


some known species: $D$. urucu (Killip \& A.C.Sm.) J.F. Macbr., D. elliptica (Wall.) Benth., D. nicou (Aubl.) J.F. Macbr., D. guianensis Benth, $D$. negreensis Benth, and D. malaccensis (Benth) Prain. Many years ago, Chinese people crushed the root in water for spraying in vegetables (Decker, 1942) and, thus, killing pests, whereas indigenous people use this plant to "tinguijar" fishes, something which means launching tingui (the ichthyotoxic plant juice) in a river to catch fish; stun or poison with tingui (Amora, 1999). One can find out in the literature that Derris sp. presented an effect over larvae of Musca domestica Linnaeus, 1758 , and it may be used to control one of the most important rural epidemics vectors (Costa et al., 1997).

Another example is the genus Lonchocarpus (Fabaceae), found out in the Brazilian Amazon region, being popularly known as timbó-venenoso or timbó-urucu, and whose root has rotenone and flavonoids which provide a toxic action over some insects. L. utilis A.C.Sm. and L. urucu Killip \& Smith were those presenting the highest concentration of rotenone ( $12 \%$ and $4 \%$, respectively) (Saito \& Luchini, 1998).

Magonia pubescens (Sapindaceae), popularly known as tingui, presents piscicidal (Coelho et al., 2009) and insecticidal activity (Souza \& Felfili, 2006), mainly due to the presence of phenolic derivatives, precisely tannins (Silva et al., 2004). Studies carried out with crude ethanol extracts of $M$. pubencens showed larvicidal activity with regard to $A$. aegypti and Aedes albopictus (Skuse, 1894) (Silva et al., 2003).

The genus Tephrosia (Fabaceae) is known as timbó-de-caiena or timbó-caa and it is represented by the following species: T. toxicaria Pers., $T$. virginiana L., and T. nitens Benth. Ex Seem. It was reported in the literature as a potentially toxic plant. These species have flavonoid rotenoid compounds in their roots (Were et al., 1990), such as rotenone, degueline, tocopherol, and tephrosine, also causing a narcotic effect (Tyler et al., 1979). The use of these bioactive compounds in the controller management in aquaculture is widespread in Europe, USA and Australia, where the ecotoxicological interactions from their actions have been widely studied (Mascaro et al., 1998).

Ethnobotanical information on the most cited timbó species with insecticidal effect are shown in Table 1. Although some plants have compounds such as pyrethrin, rotenoids, and alkaloids, few of them are commercially used (Costa et al., 1999).

\section{FINAL REMARKS}

Some insects, besides causing great losses in agriculture, bring suffering because they are vectors of organisms which transmit diseases, thus representing a strong burden, especially in developing countries, which are precisely those that can least afford it. The effect generated with the use of synthetic insecticides both for agriculture and control insect which are disease vectors causes environmental impact, in addition to affect the population health. No less worrying is the resistance created with the continuous and indiscriminate use of these chemical products, resulting in higher expenses by increasing doses until they become lethal to insects.

The use of plants by traditional populations in several activities has shown the toxic action of some plants and the possibility of applying it to fishing, as well as to the control of insects, pests, and disease vectors. This is so due to the presence of secondary metabolic compounds of these plants. In plants identified as ichthyotoxic, the flavonoid rotenoid compounds represented by rotenone, tocopherol, degueline, tephrosine, and alpha-amisyn are more easily found and they have a lethal activity over some insects. In scientific studies, the most frequently cited are the species of the genera Derris, Serjania, Lonchocarpus, Magonia, and Tephrosia. Some of these plants also can present tannins, a class of compounds with potential bioinsecticidal action.

It is important to identify natural products with desirable properties with regard to lethality of the various forms of pests and vectors, which can be used without promoting impacts whether over human health or the ecosystem; it may bring even financial benefits.

There is still a need for more studies aiming to find out for active substances which are toxic to these organisms, so that problems faced with the use of synthetic substances can be at least minimized.

\section{REFERENCES}

ABDOLLAHI, M. et al. Pesticides and oxidative stress: a review. Medical Science Monitor, v.10, p.141-147, 2004.

ALÉCIO, M.R. et al. Ação inseticida do extrato de Derris amazonica Killip para Cerotoma arcuatus Olivier (Coleoptera: Chrysomelidae). Acta Amazônica, v.40, p.719-728, 2010.

ÁLVAREZ ARIAS, B.T. Ichthyotoxic plants used in Spain. Journal of Ethnopharmacology, v.73, p.505-512, 2000.

AMORA, A.S. Minidicionário Soares Amora da língua portuguesa. 5th ed. São Paulo: Saraiva, 1999. 890p.

ANDRADE, J.N. Avaliação de extratos de Phylanthus acuminatus Vahl utilizada tradicionalmente como ictiotóxica na mortalidade de Aedes aegypti Linnaeus (Diptera: Culicidae). 2013. 68p. Dissertação (Mestrado em Biotecnologia) - Departamento de Ciências Biológicas, Universidade Estadual de Feira de Santana.

Rev. Bras. PI. Med., Campinas, v.17, n.4, p.649-656, 2015. 
ARRUDA, W. et al. Alterações morfológicas observadas em larvas de Aedes aegypti (Linnaeus, 1762) submetidas à ação do extrato bruto etanólico da casca do caule da Magonia pubescens. Entomología \& Vectores, v.10, p.47-60, 2003.

BRASIL. Medida Provisória n².186-16, de 23 de Agosto de 2001. Disponível em: <http://www.planalto.gov.br/ ccivil_03/mpv/2186-16.htm>. Acesso em: 15 nov. 2012.

CASTIGLIONI, E.; VENDRAMIM J.D. Evaluación de derivados de meliáceas para el control de Heterotermes tenuis. Manejo Integrado de Plagas y Agroecología, v.68, p.34-40, 2003.

COELHO, A.A.M. et al. Insecticidal activity of Cerrado plant extracts on Rhodnius milesi Carvavallo, Rocha, Galvão \& Jurberg (Hemiptera: Reduviidae), under laboratory conditions. Neotropical Entomology, v.35, p.133-138, 2009.

CORREAA, R.S. Toxicidade de extratos de Lonchocarpus floribundus Benth (timbó) sobre Toxoptera citricidus Kirkaldy (pulgão preto do Citrus (Sternorrhyncha: Aphilidae). 2006. 70f. Dissertação (Mestrado em Agricultura no Trópico Úmido). INPA, Manaus.

COSTA, J.P.C. et al. Teores de rotenona em clones de timbó (Derris spp.: Fabaceae) de diferentes regiões da Amazônia e os seus efeitos na emergência de imagos em Musca domestica L. Acta Amazônica, v.29, p.563573, 1999.

COSTA, J.P.C. et al. Efeitos de espécies de timbó (Derris spp.: Fabaceae) em populações de Musca domestica L. Anais da Sociedade Entomológica Brasileira, v.26, p.163-168, 1997.

DECKER, S. Inseticidas vegetais. São Paulo: Secretaria de Agricultura, Indústrias e Comércio do Estado de $\mathrm{S}$. Paulo, p.1-18 (Boletim da Agricultura, n. único), 1942.

DONALÍSIO, M.R.; GLASSER, C.M. Vigilância entomológica e controle de vetores do dengue. Revista Brasileira de Epidemiologia, v.5, p.259-272, 2002.

ERWIN, T.L. A copa da floresta tropical: o coração da diversidade biológica. In: WILSON E.O. (Ed.). Biodiversidade. Rio de Janeiro: Nova Fronteira, 1997. p.158-165.

FISHER, B.L. Insect behavior and ecology in conservation: preserving functional species interactions. Annals of the Entomological Society of America, n.91, p.155158, 1998.

HIEN, P.P. et al. Rotenone - Potential and prospect for sustainable agriculture. Omonrice, v.11, p. 83-92, 2003.

HOMMA, A.K.O. O timbó: expansão, declínio e novas possibilidades para agricultura orgânica. Belém: Embrapa Amazônia Oriental, 2004. 48p.

ISMAN, M.I. Botanical insecticides, deterrents, and repellents in modern agriculture and an increasingly regulated world. Annual Review of Entomology, v.51, p.45-66, 2006.

KOLACZINSKI, J.H.; CURTIS, C.F. Chronic illness as a result of low-level exposure to synthetic pyrethroids insecticides: a review of the debate. Food and Chemical Toxicology, v.42, p.697-706, 2004.

KOTZE, A.C. et al. Synergism of rotenone by piperonyl butoxide in Haemonchus contortus and Trichostrongylus colubriformis in vitro: potential for drug-synergism through inhibition of nematode oxidative detoxification pathways. Veterinary Parasitology, v.136, p.275-282,
2006.

KRUKOFF, B.A.; SMITH, A.C. Rotenone yielding plants of South America. American Journal of Botany, v.24: p.573-587, 1937.

LEÓN, J. Fundamentos botánicos de los cultivos tropicales. Lima: OEA, 1968. 487p.

LIMA, R.R. Informações sobre duas espécies de timbó Derris urucu (Killip et Smith) MacBride e Derris nicou (Killip et Smith) MacBride, como plantas inseticidas. Belém: EMBRAPA-CPATU, 1987. $23 p$.

LÓPEZ-ANTUÑANO, F.J. Epidemiology and control of malaria and other arthropod born diseases. Memórias do Instituto Oswaldo Cruz, v.87, p.105-114, 1992.

LUITGARDS-MOURA, J.F. et al. Preliminary assays indicate that Antonia ovata (Loganiaceae) and Derris amazonica (Papilionaceae), ichthyotoxic plants used for fishing in Roraima, Brazil, have an insecticide effect on Lutzomyia longipalpis (Diptera: Psychodidae: Phlebotominae). Memórias do Instituto Oswaldo Cruz, v.97, p.737-742, 2002

MASCARO, U.C.P. et al. Valores de $\mathrm{DL}_{50}$ em peixes e no rato tratados com pó de raízes de Derris spp. e suas implicações ecotoxicológicas. Pesquisa Veterinária Brasileira, v.18, p.53-56, 1998.

MESQUITA, M.L. et al. Antileishmanial and trypanocidal activity of Brazilian Cerrado plants. Memórias do Instituto Oswaldo Cruz, v.100, p.783-787, 2005.

MONTEIRO, J.M. et al. Taninos: uma abordagem da química à ecologia. Química Nova, n.28, p.892996, 2005.

MORS, W.B. et al. Ichthyotoxic activity of plants of the genus Derris and compounds isolated from there. Ciência e Cultura, v.25, p.647-648, 1973.

NAKATA, $\mathrm{H}$. et al. Concentrations and compositions of organochlorine contaminants in sediments, soils, crustaceans, fishes and birds collected from Lake Tai, Hangzhou Bay and Shanghai city region, China. Environmental Pollution, v.133, p.415-429, 2005.

OLIVEIRA FILHO, A.M. A resistência dos insetos aos inseticidas: a situação atual do Aedes aegypti e a explosão de dengue no Rio de Janeiro em 2002. Vetores e Pragas, v.11, p.9-13, 2002.

ORTEGA, G.G.; SCHENKEL, E.P. Ichthyotoxic activities of Ateleia glazioviana Baill and Thinouia coriaceae Brit. Journal of Ethnopharmacology, v.20, p.81-84, 1987.

PENTEADO, S.R. Defensivos alternativos e naturais. 2nd ed. São Paulo: Grafimagem, 2000. 90p.

PIRES, J.M. Ichthyotoxic plants - botanical aspects. Ciência e Cultura, n.32, p.37-41, 1978.

PIZARRO, A.P.B. et al. O aproveitamento do resíduo da indústria do sisal no controle de larvas de mosquitos. Revista da Sociedade Brasileira de Medicina Tropical, v.32, p.23-29, 1999.

RAIZADA, R.B. et al. Azadirachtin, a neem biopesticide: subchronic toxicity assessment in rats. Food and Chemical Toxicology, v.39, p.477-483, 2001.

RIZZINI, C.T.; MORS, W.B. Botânica econômica brasileira. São Paulo: EPU/EDUSP, 1976. 207p.

RODRIGUES, A.M.S. et al. Larvicidal activity of some Cerrado plant extracts against Aedes aegypti. Journal

Rev. Bras. PI. Med., Campinas, v.17, n.4, p.649-656, 2015. 
of the American Mosquito Control Association, v.22, p.314-317, 2006.

SAITO, M.L.; LUCHINI, F. Substâncias obtidas de plantas e a procura por praguicidas eficientes e seguros ao meio ambiente. Jaguariúna: EMBRAPA-CNPMA, 1998. 43p.

SHAFER, T.J. et al. Developmental neurotoxicity of pyrethroids insecticides: critical review and future research needs. Environmental Health Perspectives, v.113, p.123-136, 2005.

SILVA, H.H.G. et al. Atividade larvicida de taninos isolados de Magonia pubescens St. Hil. (Sapindaceae) sobre Aedes aegypti (Diptera, Culicidae). Revista da Sociedade Brasileira de Medicina Tropical, v.37, p.396-399, 2004.

SILVA, I.G. et al. Efeito larvicida e toxicológico do extrato bruto etanólico da casca do caule de Magonia pubescens sobre Aedes aegypti (Diptera, Culicidae) em criadouros artificiais. Revista de Patologia Tropical, v.32, p.73-86, 2003.

SIMÕES, C.M.O. et al. Farmacognosia: da planta ao medicamento. 5th ed. Porto Alegre/Florianópolis: Editora da UFRGS/Editora da UFSC, 2004. 1104p.

SOUZA, C.D.; FELFILI, J.M. Uso de plantas medicinais na região do Alto Paraíso de Goiás, GO, Brasil. Acta Botânica Brasilica, v.20, p.135-142, 2006.

TEIXEIRA, D.F. Estudo químico e avaliação biológica de Attalea excelsa Mart. Ex Spreng. (urucuri) e
Pterodon emarginatus Vog. (sucupira branca) em Aedes aegypti. 2003. 154p. Dissertação (Mestrado em Ciências Farmacêuticas) - Faculdade de Farmácia da Universidade Federal do Rio de Janeiro, Rio de Janeiro.

TEIXEIRA, J.R.M. et al. Timbós: ichthyotoxic plants used by Brazilian Indians. Journal of Ethnopharmacology, v.10, p.311-318, 1984.

TEIXEIRA, S.P.; ROCHA, J.F. As glândulas de óleo no gênero Neotropical Dah/stedtia Malme (Leguminosae, Papilionoideae, Millettieae). Revista Brasileira de Botânica, v.32, p.57-64, 2009.

TOZZI, A.M.G. A identidade do verdadeiro-timbó: Deguelia utilis (ACSm.) AMG Azevedo (Leguminosae - Papilionoideae). Revista Brasileira de Biologia, v.58, p.511-516, 1998.

TYLER, V.E. et al. Farmacognosia. Buenos Aires: El Ateneo, 1979. p.431-434.

VANE-WRIGHT, R.I.; WAAGE, J. The utilization and value of non-domesticated insects. In: COLLINS, N.M.; THOMAS, J.A. (Ed.). The conservation of insects and their habitats. London: Academic Press Limited, 1991. p.319-347.

VILLALOBOS, M.J.P. Plaguicidas naturales de origen vegetal: Estado actual de la investigación. Madrid: Ministerio de Agricultura, Pesca y Alimentación, 1996. 35p.

WERE, O. et al. Flavonoids from Tephrosia interrupta and T. linearis. Fitoterapia, v.61, p.1-372, 1990. 